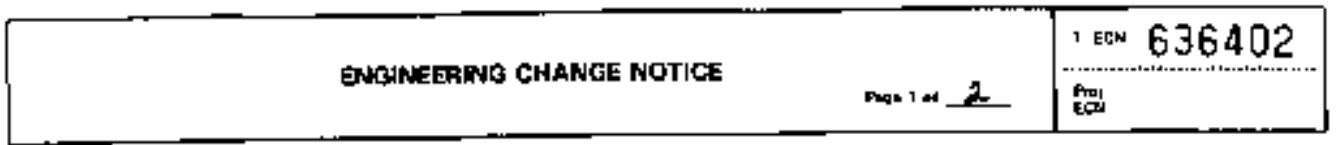

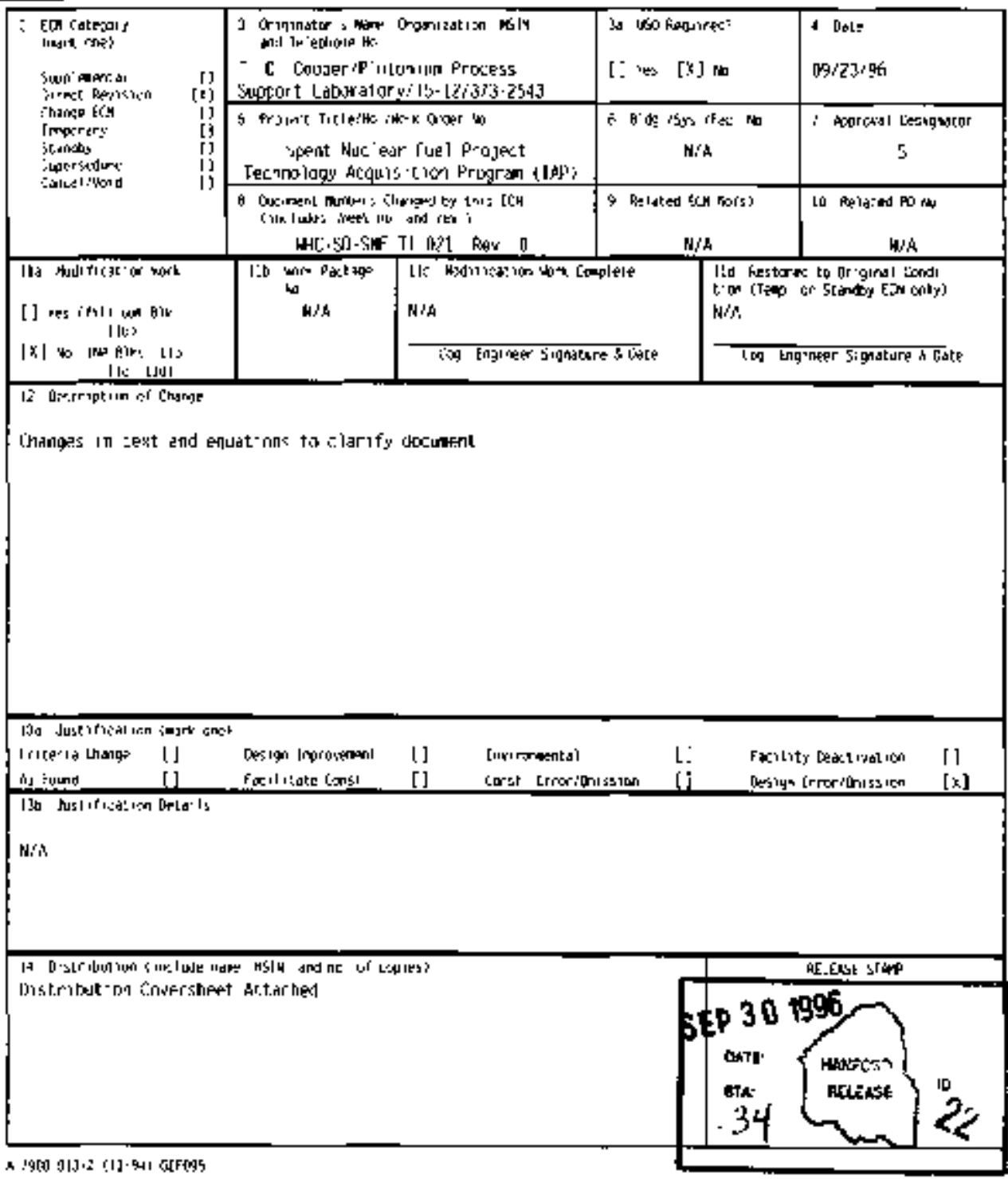




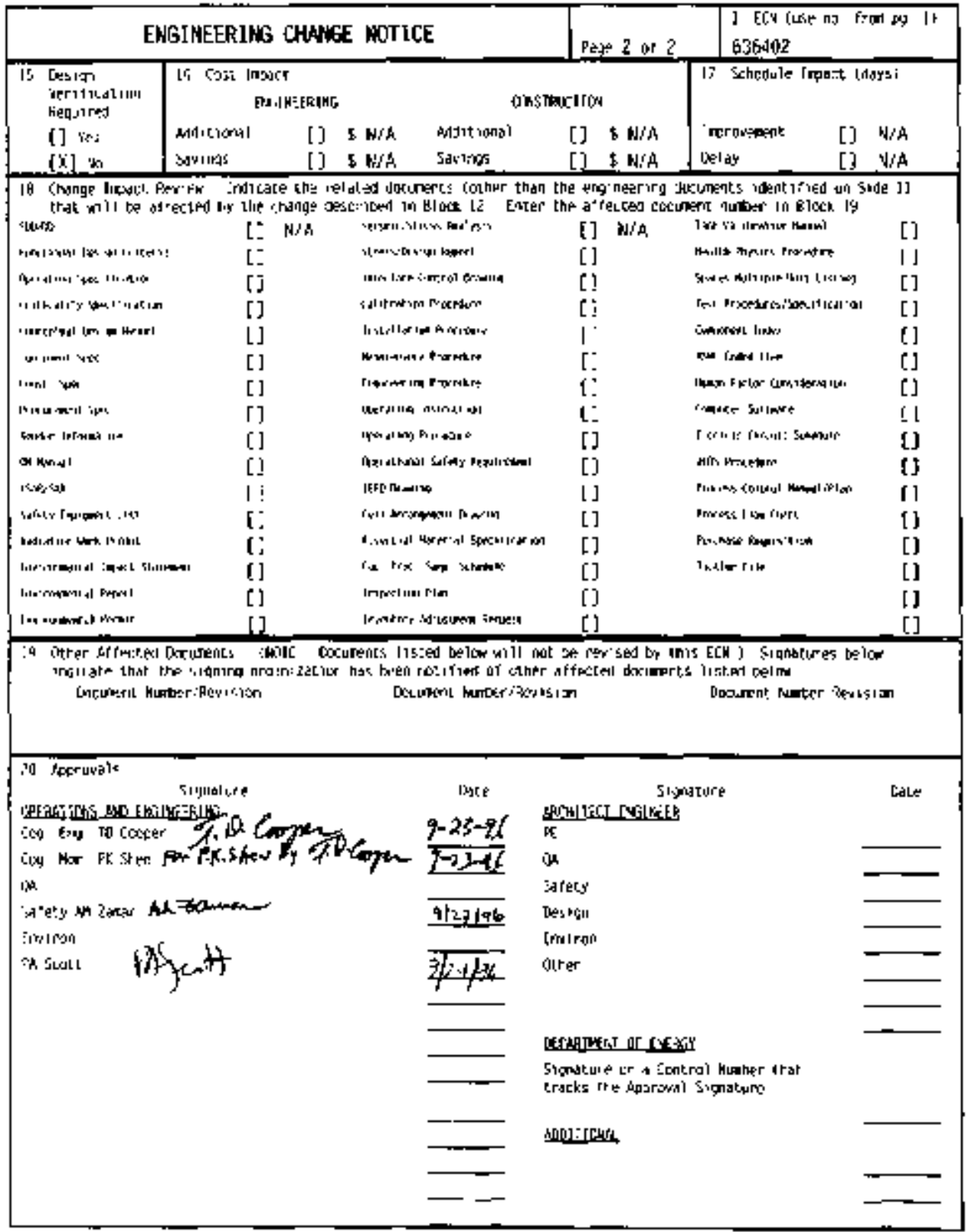




\title{
Spent Nuclear Fuel Project \\ Detonation Phenomena of Hydrogen/Oxygen in Spent Fuel Containers
}

\author{
Thurmen D. Cooper \\ Wesunghowe Hanford Corpany, Richlund, W' A 99352 \\ US Deportinent of Eiveryy Contract DF-AC06-57RJ,10930

\begin{tabular}{|c|c|}
\hline $\begin{array}{l}\text { F.DTJFCN } 636402 \\
\text { Drg Code } 15500 \\
\text { BsR Code EW3] } 5040\end{array}$ & $\begin{array}{l}\text { LC SID } \\
\text { Charge Code LBOd0 } \\
\text { 1 otal Pages Al }\end{array}$ \\
\hline
\end{tabular}

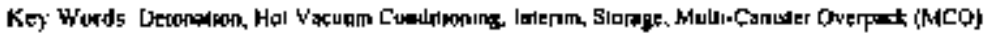

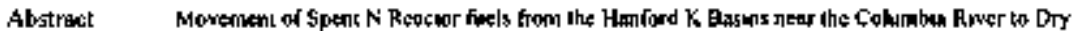

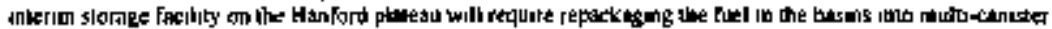

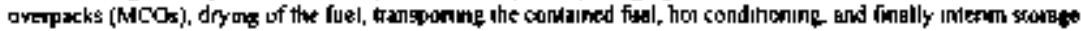

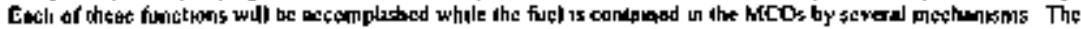

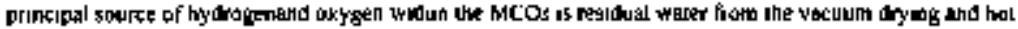

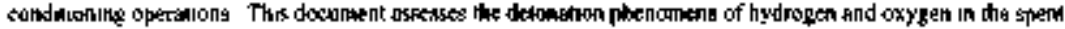
fucl conlnaners

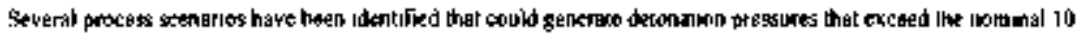

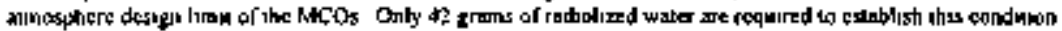

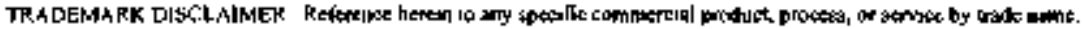

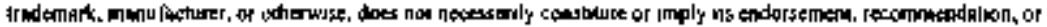

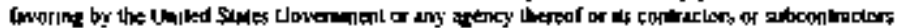

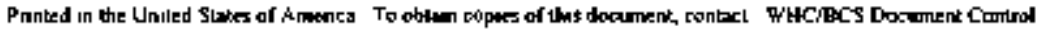

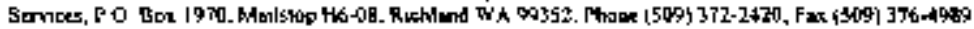
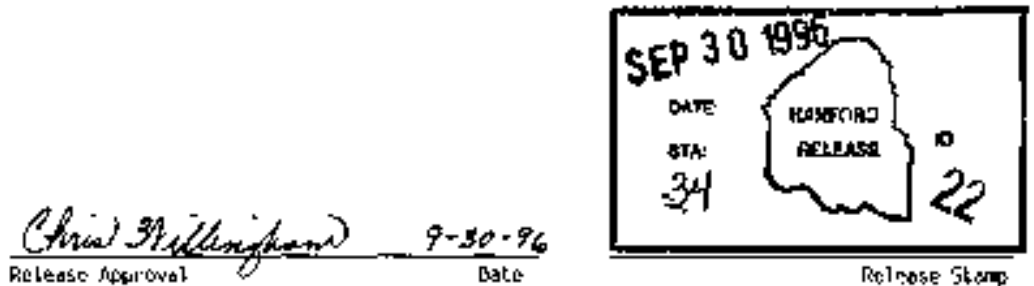

Replrose 5 kigh

\section{Approved for Public Release}




\section{RECORD OF REVISION}

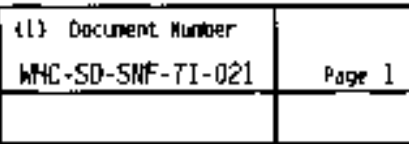

(2) Tith

Spert khc legr Fuel Project Oetonation Phenoment of Hyorogen/oxygen in Spent Fuel Contalners

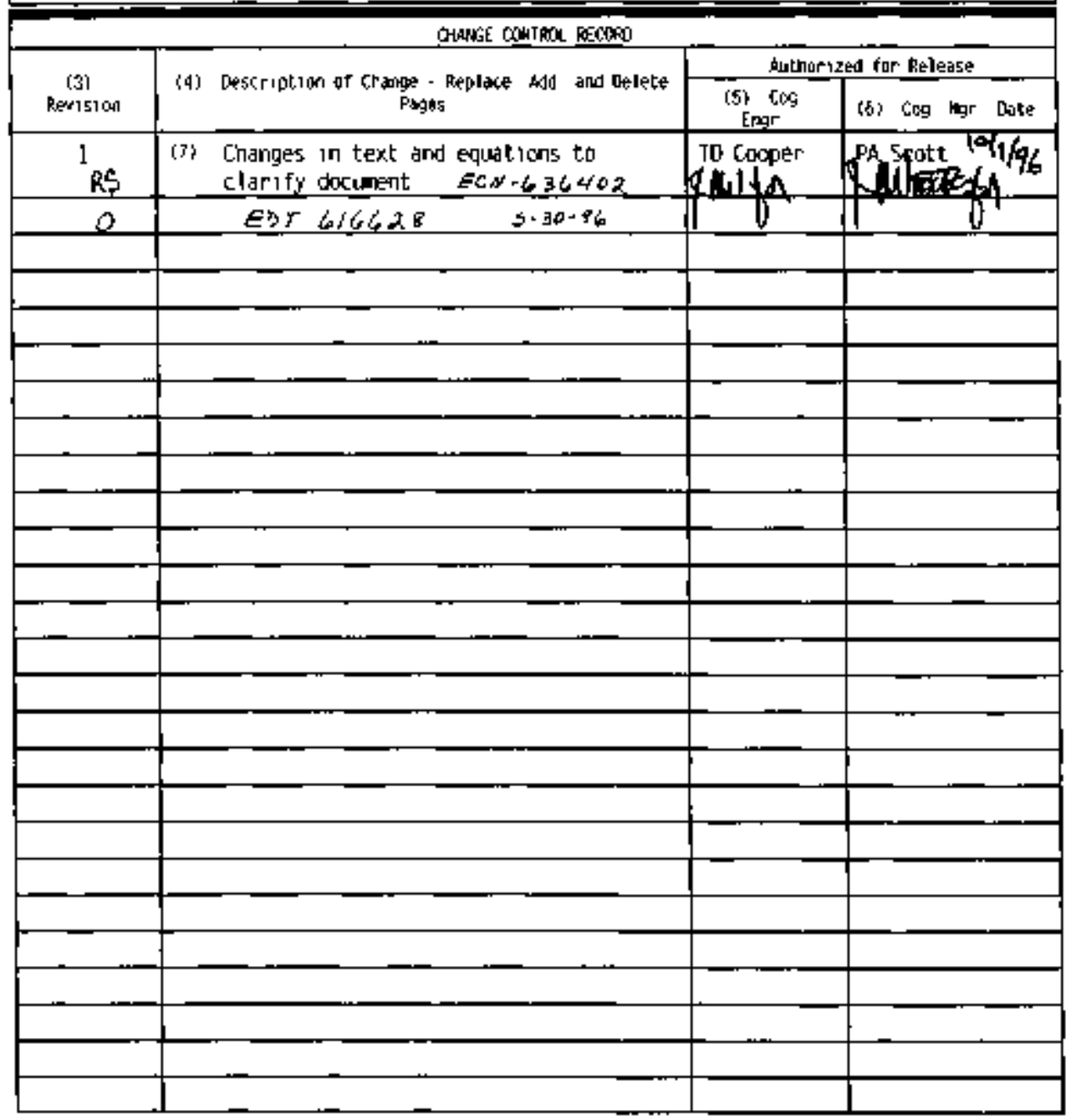

A 7323-0C5 (c8,g) HEFI GB 


\section{SPENT NUCLEAR FUEL PROJECT}

Seplember 1996

Prepaned for the UI S Departuent o1 Energy

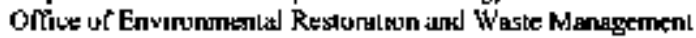

Wesunghouse Hanford Company

P O Box 1970

Richland, WA 99352 
WHC-SD-SNF-TI-D21

Revision I

This past indenbonally left blank. 


\section{CON'IENTs়}

EKECUTIVE SUMMARY

ES-]

I INTRODUCTION

20 COMBUSTION PROCESSES IN THE MOO

70 RESULTS

9

3 I FULLY FLOODED CONFIGURATION

32 COLD VACUWM BR VINO

13

3 3 SHIPPING, STAGING AND STORAGE

40 SUMMARY

SI RFFtKF:NCES

APPENDIX A

A.1

APPENDIX B

B-1 


\section{LIST OF TAELES}

I Gus Compositions Before and Following a Deknation 6

2 Detonauon Preqganc Ratios (PIF y far the Flooded MCO 11

3 Detrnition Pressure Rutio for Vatuum Sude of Pump 14

4 Detoniture Pressure Ratios fot tht Pressure Side or the Pump It

5 Deionalion Pressure Ratuss During Shipping, Siliging, \& Siorage 18

B-I Erior in Thermal Entroy

\section{LIST OF FIGURES}

I Detonatron Pregsures in Fully Flooted Configuralions 12

2 Detonation Pressures on the Vecultir Side of the Tharip 15

3 Detoration Pressures ot the Jressuec Side of the Pump 17

4 Ralto of Dcionation Prcssures to Ambienl Presgures for Shipping. Staging, and Stopage 19

5 Detouation Pressures with Varying Amounls of Water 20 
WWHC-SD-SNF-TI-D2!

Revoion I

\section{EXECUTIVE SUMMARY}

The U 5 Defparument of Energy (DOE) tsablushed the Spent Nuckear Fuel Project (SNF Ptojecl) to address safely and enyironmental concems assoejated with detenorating spem

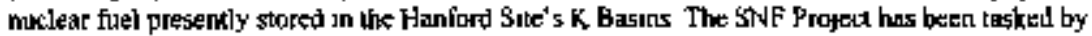

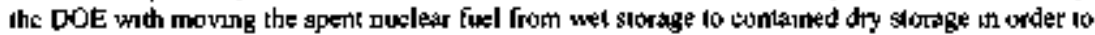

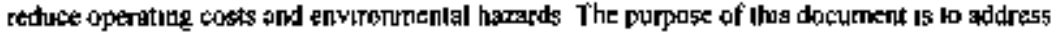
Ile dctowatien phenemenn of hydrogen and oxygen in the spent fued contasners

Although hydroken and oxyoen are not initually present in signiticant yuantulusa in the Mulit-Cahsister Overpack (MCO). they are produced by beveral mechenisms MCOs contaming damaged fuct elements where uranum fuel and resudual water are present will resul in cortosion

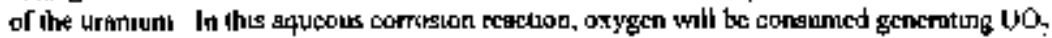
and monatomuc bydrogen Any free oxyenen would then be gelcesed by the thonatondic bydrogen Thus for an MCO secnerio where suftieknt fuel is expoged to water. frece hydrogen in an oxygent free atmosphere would be expecied Such an atmosphere (given no exiemat air in-leakage)

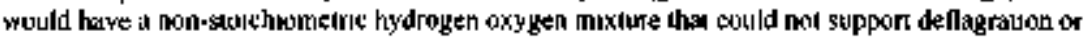
detonaluon

Radroljue decomposition of fespidtat walter, though a sjower meton proess, produces hydrogen and oxygen in a stoschnometne ratio consissent whth detsnation or defladration if is generdily agread that hydragen is relanvely nian-reactive al or near ambient iemperatures und

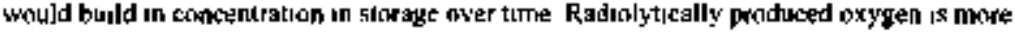
reactive and dues not adways bujld an contenifatum In an MCO wilh intact [uel assemblues.

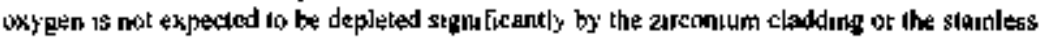

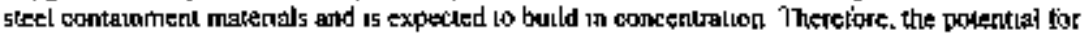
deflagration or desonation of these gascas has heen exploted

Several process configuralwns haye been idertufied whercin drtanaluon pressures exceed the noirinal $1010 \mathrm{kPa}$ ( $10 \mathrm{atmosphese)} \mathrm{pressure} \mathrm{desien} \mathrm{limit} \mathrm{for} \mathrm{the} \mathrm{MCOs} \mathrm{Onl'} 42$ grams of radiolyzed water are required to eseablish this crnditon. Unkess the driang or conditionting process car assure that less thin 42 grams of residual water are presem during sea|ced staglng or storage, a hydragen or oxygen gettenns matcnal should be present tn the MCO to atssure that the intermal almosphere will not support ilaflagration or detonetron An exygen gettering ceandidate might be a damaged fucl elemenl 
WHC-SD-SNF-TT-021

Revision 1

\section{SPENT NUCLEAR FUEL PROJECT \\ DETONATION PIIENOMENA OF HYTROGENFOXYGEN \\ IN SPENT FIEI. CONTARNERS}

\section{l. [NTRODUCTIOY}

The Spent Nuclear Fuel Project (SNF Projeci) is evaluat/ng the concept of Irangferming

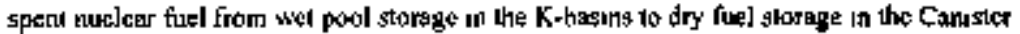
Slorage Bunling (CSB) An MC( has heen designed tn conlain and simplity handlmg of the

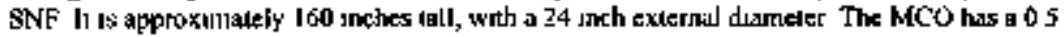

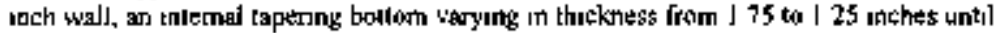

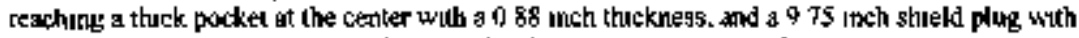
processing ports [I wi]l most likely be madc of 7nld $L$ salnless sleel li is designed ta hold a

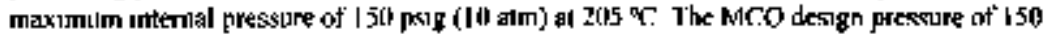

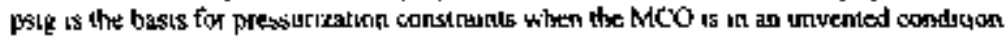

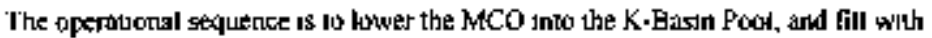

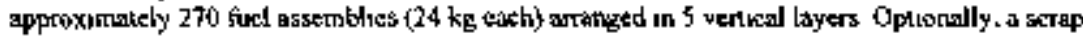
basket may be sthestituted for ane laye of tisel

$\Lambda$ fier logding, the MCO hid will be seal welded and the MCO will be usansported to the cold vacutimt drying satron, where the fire water unll be draned, and then vacuum dned at 5a-70 ' $\mathrm{C}$ NexI, the MCO will be tansported to the CSL and placed in temporary slorage in a

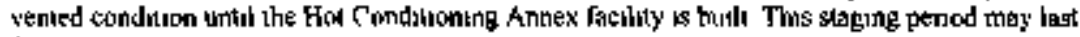
from witeral months to several years

The trot condintoming process will conss5t of heating the MCO to $300{ }^{\circ} \mathrm{C}$ under vacuum to mmove salcess of hydealion and some hydrogen from the uranum hytudes Afles hydrogen asd stater ate removed to detection or process limils. the MCU will be vooled io $150^{\circ} \mathrm{C}$ and trealed with $\sigma x y c e n$ to shabilize all remannig teacuve surlaces

F inaliy. the MCO witl be bach-filled with helum or aryon and placed in loisg-term sealed storage (nominally 75 years) During eich poocess 5lep. the potentual exustg fipr the producl|on of hydrogecn las Hydroyen can he produced by radiolyss.

$$
2 \mathrm{H}_{2} \mathrm{O}+\mathrm{Y} \rightarrow 2 \mathrm{H}_{3}+\mathrm{O}_{1}
$$

Rudpolysis, therefote. modtuces hydrogen and oxygen in approximately' the corroct




Hydrogen can atso be crealed by thenucal regttons of water thith uramum metal

$$
2 \mathrm{H}_{2} \mathrm{O}+2 \mathrm{U} \rightarrow \mathrm{UO_{2 }}+4 \mathrm{H} \cdot
$$

These hydrougel radicn|s are powsertit oxygen getterg so they deplete oxygen according to

$$
4 \mathrm{H}^{*}+\mathrm{O}, \rightarrow 2 \mathrm{H}_{7} \mathrm{O}
$$

After the oxypeus bas been depleted , hydrogen gas is produxed

$$
\mathbf{4 H} \rightarrow 2 \mathrm{H}_{2}
$$

It is therefore concluded that chermical reactrons between water and uranium result in an MCO atmosphere with excess hyidrogen atod sufficienly depleted oxygent to pose no explosive hazard Furber mixites of tbus hydrapen with gasenusg oxiduzers could, however, recreale an explosive hazard

Ths study was not designed 6 predycr the occurrence o[ an inllabing spark or high temperature event that could produce a deflagration It is nevertheless belretred that the fuel agsemblices, ag they exist it the pool, may contain some concemurations of urantum hydride Additorial hyinde will not form is the presence of oxygen, howeter, more bydnde may form whenever the MCO contalths water and is oxygen deficrest Thus bydnde nay react vigorinusly of

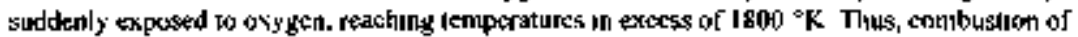
uraniutn hydrude can the added to spark sources due to mechonecal or electrocal phenomeno as portenual ugnition soutes for liydroystets

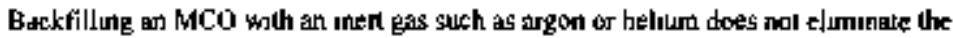
possibility of a deflegigralion or delionplion If sufficient oxygen and fuel are miked with the inert

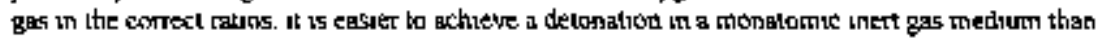

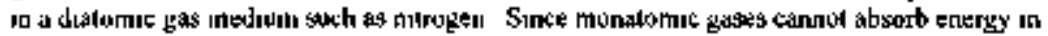
viksathonal modes, theit herat capacilh"s ire smaller than for duatome molecules, consequently, they heat more sapidly

If sufficjent oxygen and fuel are avaljable and ignted, will the sygem Irantiton from

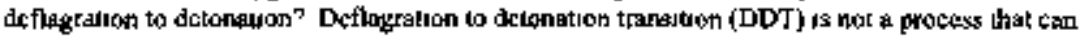
be predicted or modeled from fuudantental prunciples and is therefore apprasched empancally

Even empincal DDT dale mush be evalualed carefully Because of the many independem

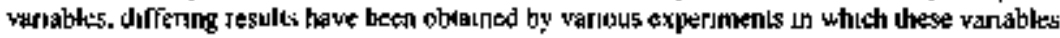
are not properly understood or controtied AE a resill. any stalements unade in thas report relative 10 a DDT cyent should he vewed as adviswy and now as a proven fact

Despite the above disclaimer, it is knowp that an inet, monalomic yas mairix contauning a stonch|omeinc hydroged axy gen mixlure in $85 \%$ atrgon at ambocnt pressure possesses a 
detonalıon cell dimenswn ot 085 pentumeter Since the voud space within an MCO v5 500 IIters. with approxumately 44 liters in the Jid's head space, ut is assumed than lhere is no dimenional testrictiou agautst detonatians for thus case Thus, g/yen an ignition source and sufficionl $\mathrm{O}_{2}$, then defoukflion withın the MCOC durng sealed storage or stagung condibons ean be expected

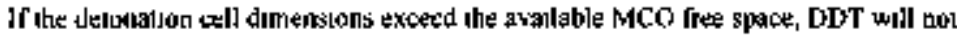
occur The detonstion cell dimensson is inversely rejated to the system heal capacily, the gas prescure, and the reaction enithalpy Based upon thess factors. Ithe vacundm process conditions would lend lo cause a larger detonativn cell Therefore, it may be possibde to sbout thet delongton condulous are nol possible during vacuum endituotung 
WHC-SD-SNF-TI-021

Rerigion 1

Th1s page themonally deft blank 


\subsection{COMBUSTION PROCESSES IN THE MCO}

IJetlagralıon is defined as the simple combuston of hydrogen and oxygen. wheren the

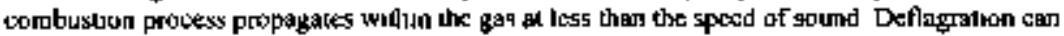
release heat and pressunze the MCO The antounl of heal reledsed is determined by the enthalpy

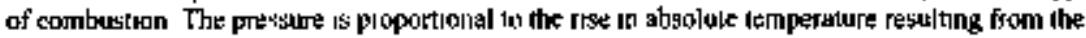
vombutan process

In conurast, a detonation waye may be uuluated by a gark or through dettagrabont to detomation iranssuon Withm the detonation wave, healung is caused by compression, and 19 aduabauc The detonatuon wave troves faster then the speed of sounid and acbieves a higher pressute and temperature than thot resulting fromn deflegratıon

The equalion relating the prespure sise in a detonation wave to the variables of the system

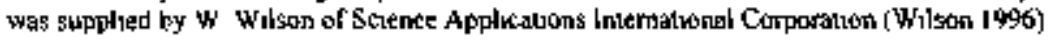

$$
\pi \times 2^{*}\left(\gamma_{1}, J Y_{n}-I+(O) / C_{1}^{*}{ }^{*} I_{1}\right)
$$

Where

$$
\gamma \cdot \mathrm{C}_{\mathrm{p}} \mathrm{C} \mathrm{C}_{\gamma}
$$

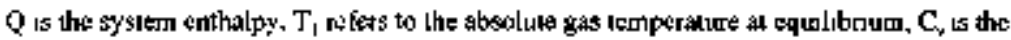
heat capacity af the system at conslant volume, and $C_{\phi} 15$ ihe heal cajacsty of the sy'stem at cunstont pressure The subsicopts 0 and I refer to the fial and inttal states of the gas This equation is based upow the inerandjnamic and thund mechasical requirements for the propegution ot it discontinuous imterfase belween reactands and producto w a flupd mediums (Landau 1993)

The mixture heat capsectlics are eshimaled from quadralic fits (Spencer 1945) to Iemperature-dependent hear capacities of Ine indrutdial compontents The exolhermicty of the

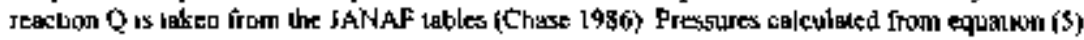
getrerally agre with expetimental measuremems within a few petcent (W/]son 1996) 


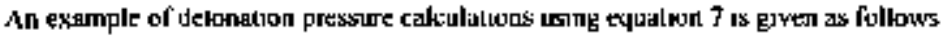

\section{Tabje I Gas Composiuons Befouc and Folkwing a Detonalon}

\begin{tabular}{|c|c|c|}
\hline $\begin{array}{c}\text { Gus } \\
\text { Syebol }\end{array}$ & Jaifinl & $\begin{array}{l}\text { Fimal } \\
\text { Moles }\end{array}$ \\
\hline$H_{2}$ & 2 & 0 \\
\hline$o_{1}$ & 1 & 0 \\
\hline$N_{j}$ & d & 4 \\
\hline Ar & 0 & 0 \\
\hline $\mathrm{H}, \mathrm{O}$ & 0 & 2 \\
\hline
\end{tabular}

F mual icmperature $=300 \mathrm{~K}$

The first step is to cvaluale the system molor heat eapacily at congant pressure and yolume, with bouth tems evaluated ar the initial condition and siso the equibrim condition

$$
\begin{aligned}
& \psi=\boldsymbol{C}_{\Gamma} / \mathrm{C}_{\mathrm{w}} \\
& C_{w}=\text { (Sug of molar leat capacilıes al consianl pressure and al initual (emperaturc) }
\end{aligned}
$$

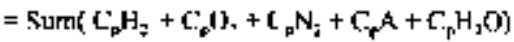

Now the individual molar hew capacilies al consuant pressure ape calculated using the collowing formulas

$$
C_{p}=A+B \Gamma=C \cdot T^{\top}
$$

where the coeffickmis A.B, ind C for each gos ane given by (Spencet 1945)

$$
\begin{aligned}
& \left.C_{\mathrm{p}} \mathrm{H}_{2} \quad-2669469-00002 * 30010000000481 * 300^{\circ}\right)=138603 \mathrm{~B}
\end{aligned}
$$

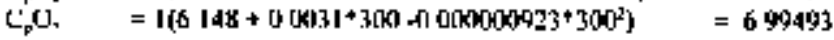

$$
\begin{aligned}
& \mathrm{C}_{\mu} \mathrm{N}_{2}=4\left(6524+00.125+300-0000000001+300^{2}\right) \quad-2759564 \\
& \mathrm{C}_{\mathrm{p}} \mathrm{A}=\mathrm{D}(\mathrm{d} 9679)=0 \\
& \mathrm{C}_{\mathrm{p}} \mathrm{H}_{2} \mathrm{O}=0 \mathrm{O}\left(72,66+0.0023+300+0000020289 \times 300^{+}\right)=0
\end{aligned}
$$

firálly'

$$
C_{r 1}=138604+6.9949+275956=48.5099
$$




$$
C_{01}=C_{\infty}-n+R
$$

$=484509 \cdot 198717^{*}(2111 d)-345408$

therefore

$$
Y_{u}=484500 / 345409-14027
$$

now is evaluate $C_{p 1}, C_{\mathrm{p}_{1}}$ and $T_{1}$ al equilibnum

$$
\begin{aligned}
& C_{n 1}=\operatorname{Sum}\left(C_{n} H_{1}+C_{n} O_{2}+C_{n} N_{1}+C_{n} A+C_{p} H_{2} O_{)}\right) \\
& \left.\mathrm{C}_{\mathrm{p}} \mathrm{H}_{2} \quad-0 \times 69469-00002 * \mathrm{C}_{1}+000000048 L^{*} * \mathrm{~T}_{1}{ }_{1}\right)=0 \\
& \mathrm{C}_{p} \mathrm{O}_{2} \quad-\mathrm{O}\left(6,48+0007 \mathrm{C}^{*} \mathrm{TI}-0.000000923 \times \mathrm{T}_{1}{ }^{2} \mathrm{j}=0\right.
\end{aligned}
$$

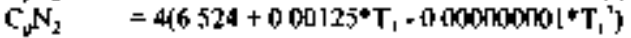

$$
\begin{aligned}
& \mathrm{C}_{\mathrm{A}} \mathrm{A}=\mathrm{O}(49679)=0 \\
& \mathrm{C}_{1} \mathrm{H}_{\mathrm{j}} \mathrm{O}=\mathrm{b}\left(\mathrm{T} 256+00023 \times \mathrm{T}_{1}+0000000280 \% \mathrm{~T}_{1}{ }^{1}\right)
\end{aligned}
$$

and now, $]_{1}$, must be known to solte for $\mathrm{C}_{\mathrm{p}} \mathrm{N}_{2}$ and $\mathrm{C}_{2} \mathrm{H}_{2} \mathrm{O}$,

Therefore,

$$
\begin{aligned}
& C_{r 1}-C_{p 1}=n * R \\
& =C_{1.1} \cdot 5^{*} 1987187 \\
& Q=57014 \text { = Molar Reachion enithalpy in calones } \\
& \left.\mathrm{T}_{1}-2^{*} \mathrm{Q}^{*} \gamma_{1}^{*} \text { Moles of Product } \boldsymbol{H}^{*} \mathrm{C}_{\mathrm{w}}{ }^{*}\left(\gamma_{1}+1\right)\right)
\end{aligned}
$$

Solvng tquaterns $12,13,14$ and 15 teratuely for $T$,. we find

$$
\begin{aligned}
& T_{1}=2315.53 \mathrm{~K} \\
& C_{n 1}=659670 \\
& C_{.1}=540440 \\
& Y_{1}=12206
\end{aligned}
$$

so finally firom equatian (5) in the main iext

$\left.\pi-2^{*}\left(Y_{1}-I\right)\left(\gamma_{0}-1\right)\right)^{*}\left(Q i C_{\infty} * T_{1}\right)$

$-120566$ 
WIIC-SD-SNF-T1-02I

Revision I

Thıs page untentıonally laf́ btank 


\subsection{BESULTS}

7 wo questions are petunent to this repon thill a deflagratron or detontuon oscur" And,

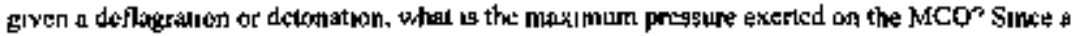
detanation provides the highest iemperilumes and pressures, all subsequerit analyges wall he focused upon dketwarion tevents

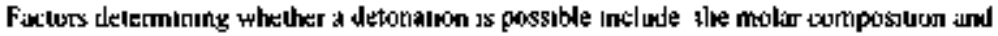
pressuras of the gaces, the heat capacily of the gases, the inilal temperalure of the gases, and the neccurrence of an initiatung event guch as a spark or high tempersint

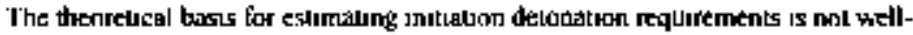
developed and its sludy requires an empirical basis Three calegones of imilatsons are commonly shudred stock-10.detassation transition Jet-to-detonation transition. and deflagration-k0-

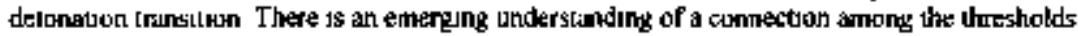
For ench unvolving the fundamental suructure of the detonalion front (Fickert I979 and Let 1984)

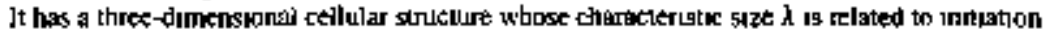

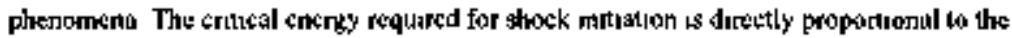
wolume of the inutsation cell, while fet unitialon sequires an crilice diameter of I3 $\lambda$ DDT has been shww to aceur an hydrogen-aLr-sleam muxtures when the lube diameter reaches the $\lambda$

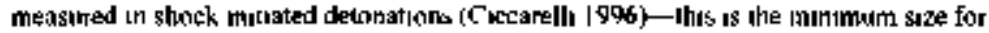
detonatich propagatron regarlless of the intaition mode

DDT is a complex process not atheshable to a poor madeling predichon lis noculreuce

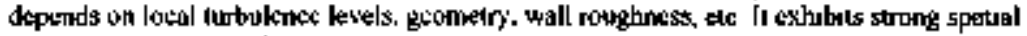

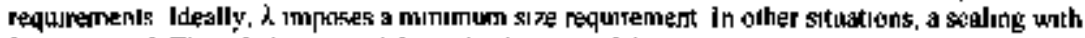

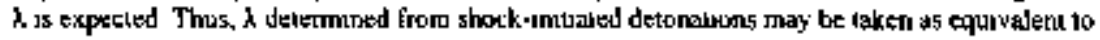
the requirements tot DDT

Storchiometnc liydrogen aur mixtures al lot $\mathrm{kPa}$ (1 alroosphere) pressurc have an

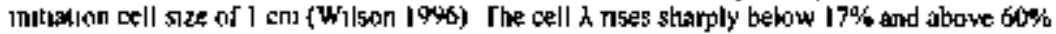

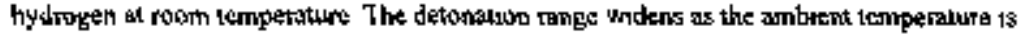
increased Cell size dato in hydrogen-oxygen-argan mixtures have treen established over wade ranges of pressures and dilutions (Sirelilow' and Eingel 1969) Their daba show that in uл $85 \%$ argon-15\% atsichiometric axygen/hydrngen mixture at I almospthere pressure, a cell with

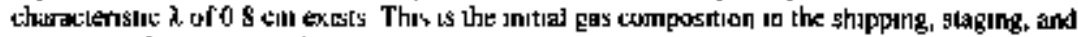
storage configuration producung a $1010 \mathrm{kPa}$ ( 10 almosphere) detonean wave Ther dete also

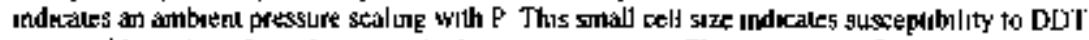
comparable to that of stouchomctric bydraget-aur muxtures There ate no confirming measurements of DD'I in these systems at pressures above atmosphene (Clocarellı 1996) 


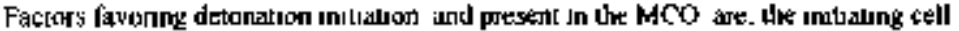
dimensuong are amall, and all MCO's may potentially contain in|lialung sounces such as urahıum hydnde andfor mechancally or electncaliy induced spaiks An imilgung event is therefore assumed, and the remanning emphasss is placed upen evaluatung delonation syaye preggures is the MCOs

\subsection{FULLY FLOODED CONFIGURATJON}

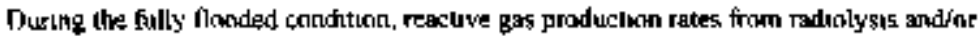
chemical rescions are or Lan be maximized, and wond spaces uithin the MCO may axcumulate hydrogen and oxygent thus flooded configuration must theretione be analyzed fins uts detonation potential for this conditun, the following parameters are usisumed

- an ar gap exists within the NCO head space,

- the intial presaure is $10 \mathrm{kHa}$ (I timnophere).

- the hydrogen/oxygen ralio is stoichsonsetric,

- the hydroger combentation ranges From 00 to $90 \%$ by yolume, and

- the temperative nioge is from 25 to $1000^{\circ} \mathrm{C}$

Under these conditions, the pressure unereoses stovivi u Tabde 2 are calculated The

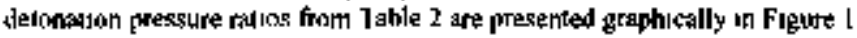

Figure I shows that delonation pressures are hughest in all cases at 30\% hydnoges by volume. that the pressutes decrease whth increasing Initial temperalure, and that several

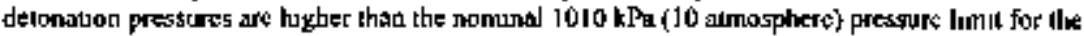
MiCO The maximum detonation pressure in ine fully fhonded configuration is $1313 \mathrm{kPa}$ i 13

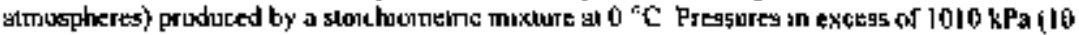
atmospheres) are posstitle for mixitures fibon 17 to 57 volume percent $\mathrm{H}_{2}$ At higher imtial pressures, the muxture range capabse of creaung a detonaduon pressure bighes than $1010 \mathrm{kPa}$ ( 10 atmospheres) thidens beyond 17 lo $57 \% \mathbf{H}_{2}$

The probabplily of DDT occurring is related is the hydrogen soncentralion Although predjcting DUI is not an exact science, it is belreved that DDT oceurs most often wilhis the 17 to 57 volume pervenl hydragen ange 
Table ? Detonalmun Pressure Ratos $\left(\mathrm{PI}_{\mathrm{p}}\right)$ for the Flooded $\mathrm{MCO}$.

\begin{tabular}{|c|c|c|c|c|c|}
\hline \multirow{2}{*}{$\begin{array}{l}\text { Yumene } \\
\text { Percent } \\
\text { Hydroten }\end{array}$} & \multicolumn{5}{|c|}{ Temperoture ( $\left.{ }^{\circ} \mathrm{C}\right)$} \\
\hline & $2^{\circ}$ & $25^{\circ}$ & $50^{\circ}$ & $15^{\circ}$ & $140^{\circ}$ \\
\hline 0 & - & . & . & - & . \\
\hline 10 & 6718 & 6154 & 5678 & 5270 & $4 \$ 17$ \\
\hline 20 & 1093 & $100 \mid$ & 9236 & 8572 & 7998 \\
\hline 30 & 1314 & 1704 & II II & 1031 & 9617 \\
\hline 40 & 1221 & 1119 & 1032 & 4582 & 8940 \\
\hline 50 & 1111 & 1019 & 9398 & B 72,3 & 8138 \\
\hline 60 & 9793 & 8472 & 8277 & 7683 & 7168 \\
\hline 70 & $8] 45$ & 7462 & 6884 & 6390 & إ) \\
\hline 80 & 6034 & 5528 & 5100 & 4734 & 4417 \\
\hline 90 & 3294 & 3016 & 2784 & 2584 & 2411 \\
\hline
\end{tabular}


Figure ] Detonalıon Pressures in Ful]y Flooded Configunalıons

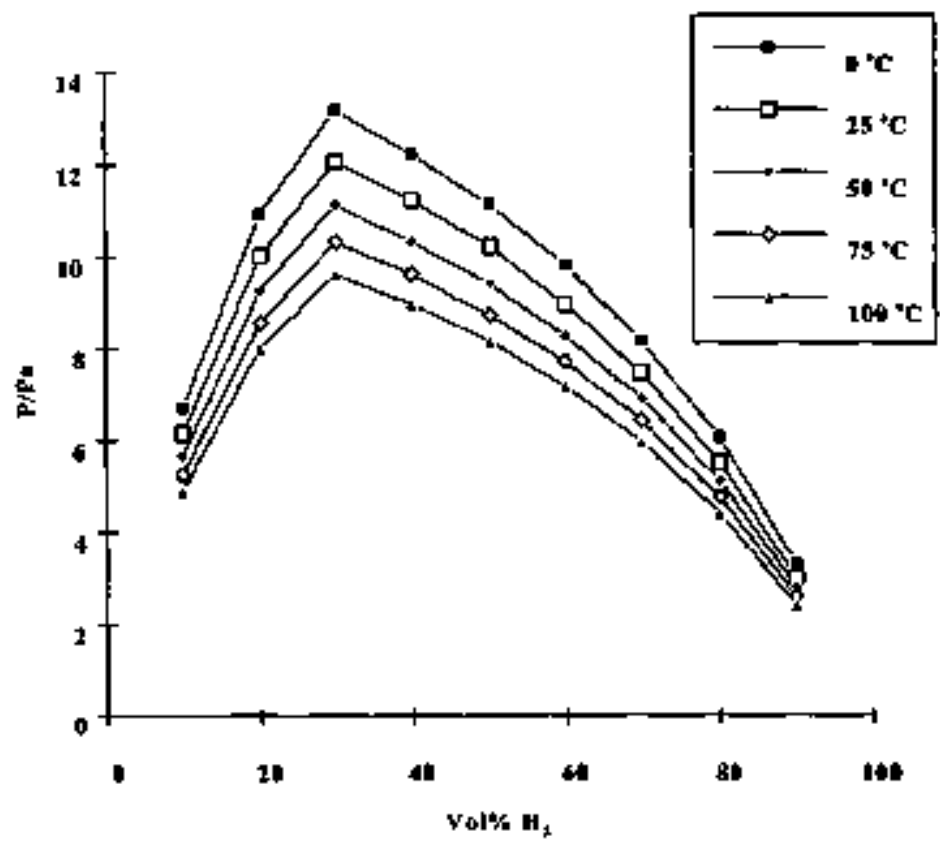




\subsection{COLD VACUUM IHRYING}

'The 11exi process condinon analyzed was the detonation. pressure on the low pressure side of the vacuum pump At the tume this documem was prepared, no firm guidance had been issuced hy the proyect on the enacil vacuum pump to be used The operational pirameters chosen were

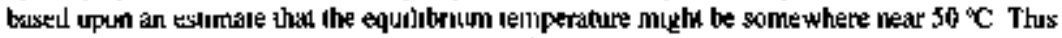
would support a water vapor partal pressure ot $1196 \mathrm{kPa}$ to $1329 \mathrm{kPa}$ (90 to I00 torrit The extent of contyessson of that waler vapor to hydrogen gas by chemical reacison was not clear

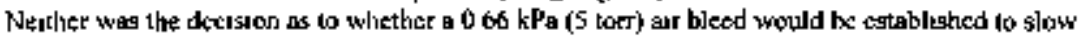
the aqueous comosion rale

The following parameters were therefore assumed for this case

- Water vapor partal pressure is $1993 \mathrm{~Pa}$ (15 torr).

- Oxygen partial presare is 1329 Pari int)

- Nitragen parcial pressure is $5316 \mathrm{~Pa}$ (4 torr), and

- Hlydragen parial gressure is $1329 \mathrm{~Pa}$ 10 $1329 \mathrm{kPa}$ (I-I00 totr)

Tithe 3 presents the pressure ralos cidculaled from equaton (5) The Table 3 detonatron pressure ratio data are presented graphically in Figure 2 
Table j Deknntion Pressure Ralio fór Vacuum Slde of Pump

\begin{tabular}{|c|c|c|c|}
\hline \multirow{2}{*}{$\mathrm{H}_{2}(\mathrm{~Pa})$} & \multicolumn{3}{|c|}{ Temperatare $\left({ }^{\circ} C\right)$} \\
\hline & $50^{\circ}$ & $75^{\circ}$ & $1 \mathbf{a s}^{\mathbf{n}}$ \\
\hline 1329 & 27001 & 25061 & $2338 \mathrm{~L}$ \\
\hline 1329 & 37483 & 34791 & 324,59 \\
\hline 2658 & $30 \$ 82$ & 28385 & 26482 \\
\hline 3987 & 25654 & 23811 & 22215 \\
\hline 53$] 6$ & 22006 & 20475 & ] 9056 \\
\hline 6645 & 19220 & 17859 & 166043 \\
\hline 7974 & 170.34 & I 5*Ith & I d75. \\
\hline 9303 & 15279 & 14581 & 13231 \\
\hline 106372 & 1,3842 & 12847 & I 1986 \\
\hline 11961 & 12646 & 11738 & 10951 \\
\hline 13290 & 116.36 & 10800 & 10077 \\
\hline
\end{tabular}


Figure 2 Delondion Presgures on the Vacunum Side of the Pump

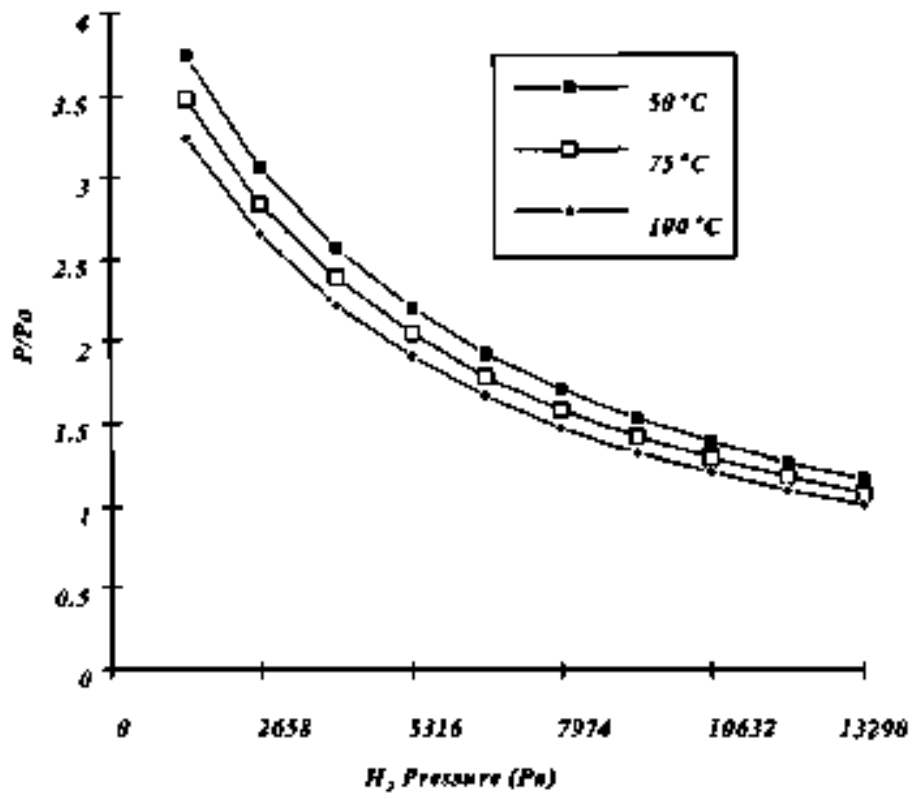


Fugure 2 shows that the detonalron presgures are quite low on the vecunum sude of the pump and never excecd 02 amospherc There is therefore no danger of a sereous overprassunzation of the MCO while under vacuum

On the pregsinc sude of the pump. the unulal purameters are at follows

4. Oxygen parital pressure is $20 \mathrm{kPa}$

- Nitrogen parthal pressure is $80 \mathrm{kPa}$.

- Hydrogen paryal pressure usept between $04 \%$ by dilution, and

- Warkr partial pressure is I $26 \mathrm{kPa}$

Linder these condinons, the hydrogen detoninon pressures are calculated and presentiod w Table 4 These results are presented graphreally in Fugure 3

Table 4 Detonabon Pregaure Rinios for the Preasure Side of the Pump

\begin{tabular}{|c|c|c|c|}
\hline \multirow{2}{*}{$\begin{array}{c}\text { Volwne Percent } \\
\text { Hydrogit }\end{array}$} & \multicolumn{3}{|c|}{ Tenperature $^{\circ} \mathrm{C}$} \\
\hline 0000 & - & - & $100^{\circ}$ \\
\hline 0005 & - & - & - \\
\hline 0010 & - & - & - \\
\hline 0015 & 1086 & 1009 & - \\
\hline 0020 & 1412 & 1310 & 1272 \\
\hline 0025 & 1722 & 1599 & 1492 \\
\hline 00030 & 2020 & 1875 & 1749 \\
\hline 0075 & 2306 & 2141 & 1997 \\
\hline 0040 & 2582 & 2396 & 2236 \\
\hline
\end{tabular}


Figure 3 Defonation Pressures on the Pressure Side of the Pump

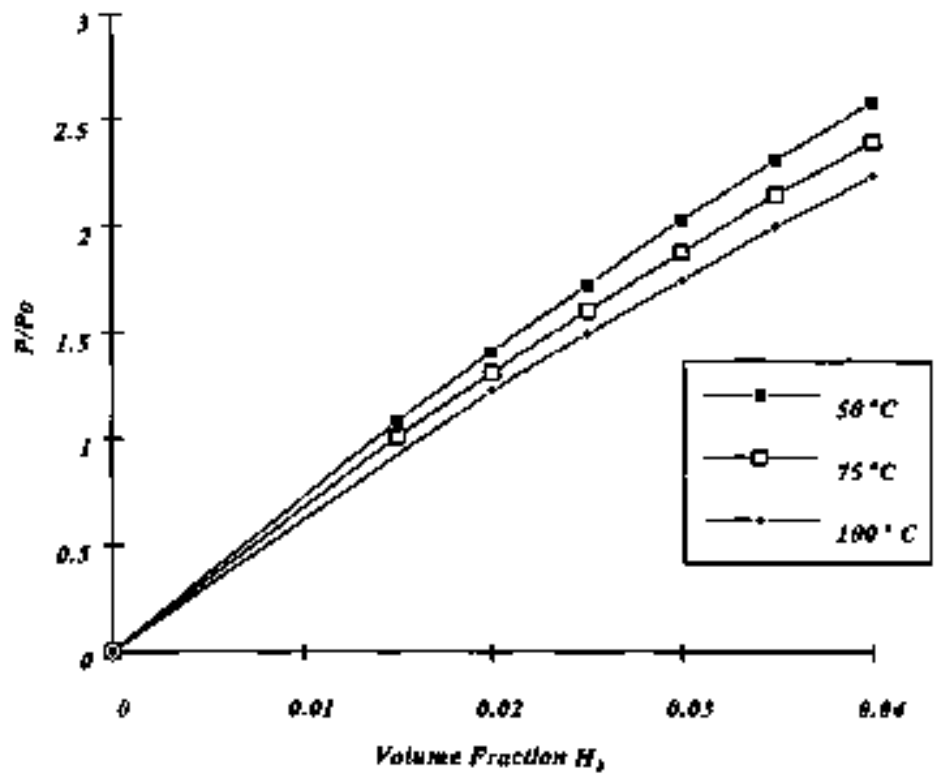


Figure 3 showg that detubation pressures never exceed $303 \mathrm{kPa}$ (3.1 almogpheres) th the presaurc gade of the pump while bye hydrogen volume fracion is mandanned less than $4 \%$ by dilution The exhaust gas plemm anut be desiened to survive pressure waves of this magnilude

\subsection{SHIPPING,STAGING, AND STORAGE}

Dunng shupplig, staging. and storage the following paramelers are assumed

- The atrockphere to to be unert gas such as utgon,

- Initul pressure ranges thom 101 to $1010 \mathrm{kPa}(1-10$ attonospheres $)$.

- Temperalure range = 50-150 " C.

- Hydrogent to argon ratpo range $=5$. and

- Ilvadromeal ka axygen ratin equals l

Using these parameters, the detonavon pressure ratio was calculaksl and is presented in Table 5 Talole 5 delonation pressure ralios are presented grapbically un Figure 4

Table 5 Detonation Pressure Ratios Dunng Shppong, Slaging, \& Storage

\begin{tabular}{|c|c|c|c|c|c|}
\hline \multirow{2}{*}{$\begin{array}{l}\text { Hydraget to } \\
\text { Argen Retio }\end{array}$} & \multicolumn{5}{|c|}{ Tempexature ${ }^{\circ} \mathrm{C}$} \\
\hline & 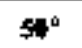 & $75^{\circ}$ & $100^{\circ}$ & 145 & $150^{\circ}$ \\
\hline 001953 & $2 ! 64$ & 20,208 & 874 & 1756 & 1652 \\
\hline 00391 & 3494 & 3712 & 3463 & 3246 & 3054 \\
\hline 00781 & 6759 & 6273 & 5853 & 5485 & 5161 \\
\hline 01503 & 9914 & 9202 & 8585 & 8040 & 7576 \\
\hline 0.3125 & 1246 & II 57 & 1079 & 1011 & 4517 \\
\hline 06250 & 1390 & 1291 & 1204 & 1128 & 1062 \\
\hline 125 & 1447 & 1343 & 1253 & 1174 & 1105 \\
\hline so & 1458 & 1353 & 1263 & 1184 & 1114 \\
\hline
\end{tabular}


Figure 4 Ralio of Dhetonation Pressures 10 Ambsent Pressures for Shipping, Stagrne, and Storsgc

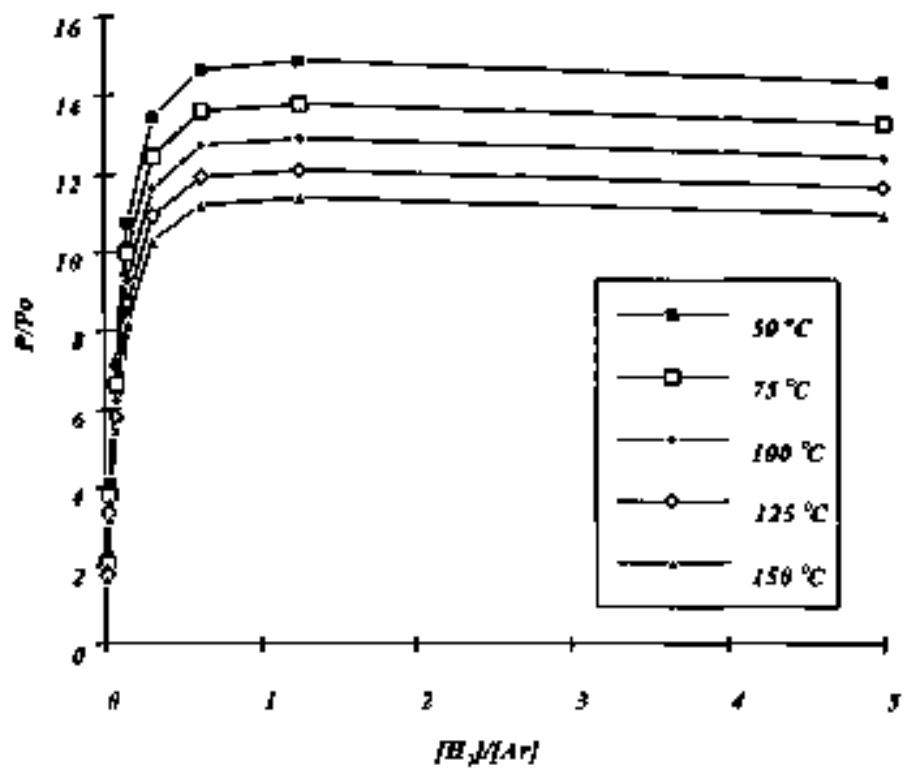

figure 4 demonstrates ital almosl all of the presaure raulos are ahove 10 and are relatively invaniont for hydrogen to argon ratuos abouse 05

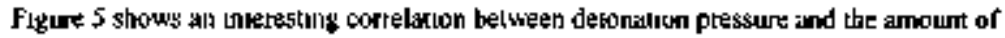
wates radjolyzed is the $\mathrm{MCO}$ 
Figure 5 Detonation Pressures with Varying Amownis of Waler

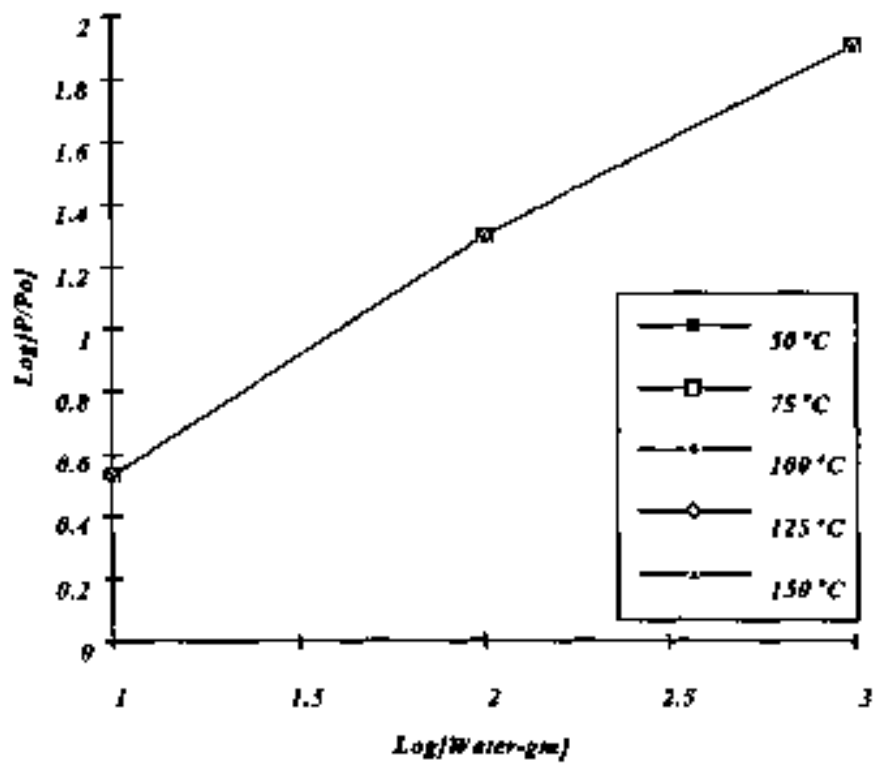

According 10 Figure 5 , only $\$ 2$ grams of water fadiolyzed in the MCO afe required to

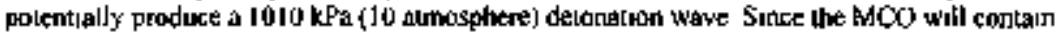
uyer 6 tons of fuel, vetIfying than the MCO contaths kess than 42 gatams of water scems a dauruting chalienge 


\section{d.* SUMMARY}

Ignuton and subsequent delonatuon of hydrogenfoxygen mixtures in the MCOs is

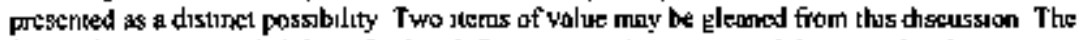

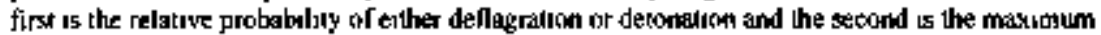
pressures achiesed in a detonation

A] though this repart has not doscussed the firsl stem in detal (the probebulity at deflagrauon or DDT), 11 thould be recognized hat such deflagration or DDT is thofe likely us the upper thalf of the area below each of the pressure ratio curves in Figure i Since PIPo is

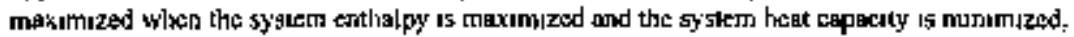
under these condisons, the lowegl minmum spark energieg and the smallest delonation ceil dimenatons art encoumiered

It therefore seems likely that more experimental systems will meet the modumidm requirements tor delonatyos und that detonstion us therefore more pobable It this sense. the probabulity also increages for hydrogen'oxygen mixitues, as the hydrogen lo argon molar taluo increases toward I. as shown in figure 4

Given the possibility al an igniluw leading in detoliation, the main tocus of this paper has been on the therwodynamic energy potenlual of the systerc and the detonatron pregsures that

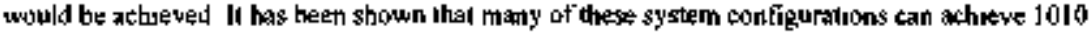
kPa ( 10 atmospheres) or mure in the detunalion wave It has also been shown that dunng Jongterm storage, the mdjolyss of only 42 grams of waler 15 regunned to produce a hydrogen/oxygen

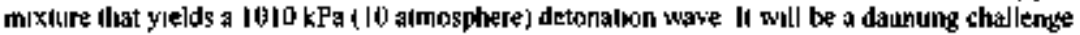
to prove that the system does not contain 42 or more ermens of water when placed tp long-term storage 


\section{5.\$ REFERENCES}

Barrow, (j M . Physroat Chemestry, MeOraw -Hill, 1961

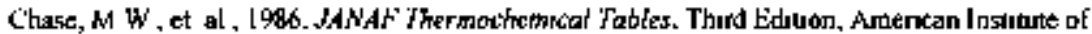
Physies, New York, New Yock

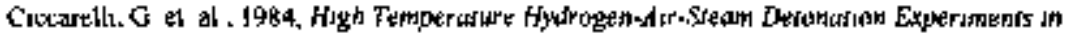
the BNL Sould Scale Development Apparatu, NUREG,'CR-62I3, BNL-NUREG-\$2414

Ficketr, W and Davis, W C , 1979, Detonatıon. University of Caluforna Press, Berkeley, Calıforme

L.andal, I. D and ] , Ifshulx E M , 1993, Fiud Mechumies, Pergamon Pregg

Lee, J H S, 1984. Dymame Properties of Ginsom Detonationt, Flund Mechamics, 311

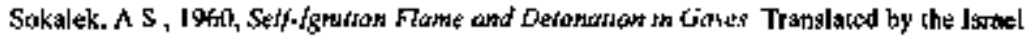

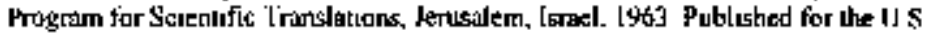

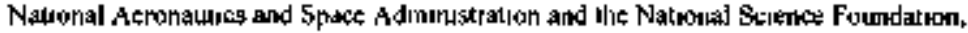
Washingirn. $0 \mathbf{C}^{\circ}$

Spencer, HM , 1045, 1ACS 67, 1858

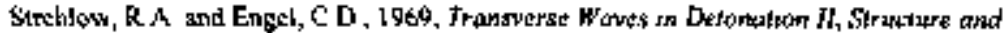
Spactitg in H2-1)2 Swatests, AJAA 7492

Wilson. W' . 1996, Pruate Compuncatwor, Scuence Applealkns Intematinnal Corporation, San Dreso, Cul|10m|a 


\section{AFPENbLX A}

\section{DETONATION WAVE THEORY}

Equagon (5) in the man text was presented and used to gentegate the derontuon pressure

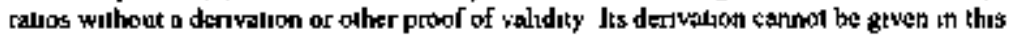
appendix. sunce we do nol have ready access tis the source matent As a gecontary possitun, the

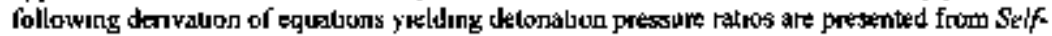

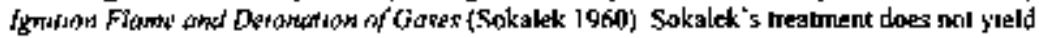

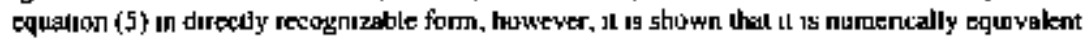

\section{Simple Shock Wave}

A shock wave may be represented as the result of the Hery raptd tompresson of gas

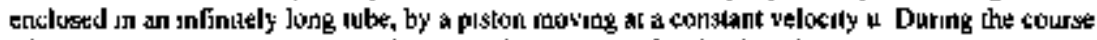
of ane second in which the piston has moved a dislance of $u$, the distunthance caused by the compression travels a dustarue $\mathrm{C}$ ar the high, bul fintte velocity $\mathrm{C}$ lin such a case, the undistunted gas is separated twous the compressed gas by a boundary acrosg which thene exsts an atwupt

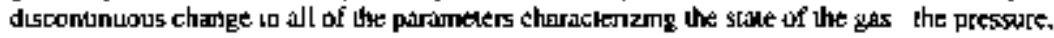
densty. specific yolume, tempirature and velocily The boundary reptisents the shock wawc firnt C., then is the propagatinn vekncity of the shock wave with respect tor the undusturbed pas, it is the velocily of the piston and of the ges flow behind the shotk frond. and C-u is the propagalion velocily ot the shock wive with resprect to the compressed gas

The applicasuon of the conservation laws to the states of the undisturbed and the compressed gos (deroded by the subscrapts of 0 and I) leads $k$ three equations The mass conservation equation

$$
\text { or } \begin{aligned}
& C P_{n}=(C-4)+P_{1}=M \\
& C r V_{v}-(C \cdot+1), V_{1}=M
\end{aligned}
$$

The momentum conservation equailon

$$
\begin{aligned}
& C P_{v}{ }^{*} u=p, \cdot p_{v} \\
& \text { or } \\
& c * w v_{r}=p \cdot \rho_{n}
\end{aligned}
$$

and the enirgy Lonservalion equaliout

$$
\text { or } \begin{aligned}
& P_{1}{ }^{x} u-P_{*}^{*}{ }^{*} *\left(E_{1}-E_{2}+u^{2} / 2\right) \\
& P_{1}{ }^{*} u=C \sim v_{*} *\left(E_{1}-E_{0}-u^{t} / 2\right)
\end{aligned}
$$


The quantily M. in equation (AL), is 1he mass of gey passing through I $\mathrm{cm}^{3}$ of the shock wave surface dungg one second and 19 usually known as the mass gas velocity (mas5-flow rate)

Equation (A3) states thal the work done on the gas equals the unceremeal in its ithernal and knetic energers Here $\rho$ is the detrisly, $V$ is the specific volurae. and the us the internal energy per

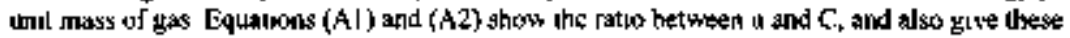
quantilies as funcuong of $\mathrm{P}$ and $\mathrm{V}$

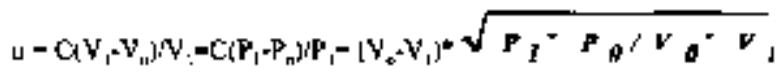

and

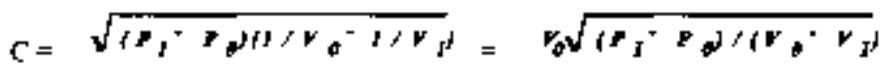

I C and u from equations (Ad) and (AS) are substruted intv tauaton (A) ), the energy conservation equation becomes

$$
E_{1}-E_{*}-\left(V_{0}-V_{1}\right)^{*}\left(P_{1}+P_{0} / 2\right)
$$

For an ideal gag, the intemal energy is

$$
E=P+V / k=1
$$

The dcrivation of equation (ATh is presented in Appendix B,

so.

$$
\left(P_{1} * V_{1} /\{k-1)\right]-\left(P_{0}+V_{11}(k-I)\right\}=\left(P_{1}+P_{n} / 2\right)+\left(V_{0}+V_{1}\right\}
$$

whuch may be iransformed into

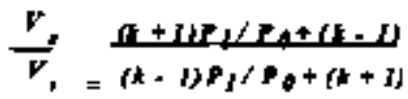

giving the relatoon betweec the decree of compression rallo, $t=V / N,=\rho, p_{*}$ and the pressure rise $\pi=P_{1} P_{0}$ un the shock wowe Equations (A6) and (A9) are the squaluons for the dynamic compressob in a shock wave and are known as the Hugonio adiabate ( $\mathrm{H}_{2}$ ) 
Equation (A6) leads to some exptessians that are useful for detenmining the relatrye pressure rise and acmperature tusc it as functions of the compression ratao $e$

$$
t=\frac{\epsilon(h+H)(k-H)}{(k+I) \cdot E(2-1)}
$$

now snee

$$
\begin{aligned}
& T_{1} / T_{0} \Rightarrow P_{1} V_{1} / P_{n} V_{n} \\
& \left.\Delta=\pi / \ell=\{] i_{\varepsilon}\right)((\varepsilon ;(k+1)-(k-1)) /((k+1)-E(k-I))
\end{aligned}
$$

Finsilly the quantines $\mathrm{C}$ and $u$ cap also be expressed as fupctions of $\mathrm{E}$ and $\pi$

$$
C=\left(P_{*} Y\right)(\pi-\mid W(j-1 / c)
$$

and

$$
\|\|^{3}=P, V_{u}\left(1-1 / \varepsilon_{e}\right)(\pi=1)
$$

for strong shock waves in wheth $\pi>10$, the tems $(k-1)$ and $(k+1)$ ith the gumeraler and denomisaror of equation (AS) may be negleteted so that

$$
\text { e. }(k+l)(k-1)
$$

consequenuly.

$$
\left.\left.C^{2}=P_{0} V_{0}(t k+1) / 2\right) \pi \cdot 1\right)
$$

ar

$$
\left\{C C_{n}\right\}=\{h+1 / 2 k\}(\pi-h)
$$

if it is taken inte arcount thal

$$
\mathrm{NRT}_{*}=C_{n}^{2} / k \text { or } k=C_{n}{ }^{2} / P_{*} V_{\text {, }}
$$

R. 15 the untwersal gas constanl and where $\mathrm{C}_{0}$ as the velocity of sound in the gas in its Int|11\%al siale

Lel las now consider the main difterences helwein dynanse compresson in a sinock wave end ordingry adiatalue compresanon actording to the Ponsan law

$$
\left(V_{,} / N_{1}\right)^{ \pm}=P_{1}, P_{0}
$$


These differences exisi because the compresson un a slock waye occurs with a finite displacemem and mass flow sate, whuke in ondinary compression these quantobes ane infinitesimal

\section{The Stalionary Detanatien Wave}

A delonatot waye, which is a shock wave accompanied by reactoon, to described by the

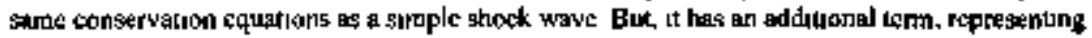
the heat of chemical rencloon, iccluted in the entefay consefvalion equituon

$$
F_{1}, F_{71}=\left(V_{0}-V_{1}\right)\left(P_{0}+P_{1}\right) r 2+Q
$$

The conservalion of momenturo in the equation analogous to (A2) and the conservalions of energy in equatuon (A.IS) tefer to the itulual and final reacuton states (complete liberation of the

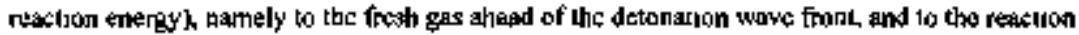
producis behind the front, afier thermodynamic equilibrium has been established if the change in the interial entergy Lo once agann whitcil as

$$
\triangle E-\Delta(P V Y(k-1) \text {. }
$$

then the pressure as a funcuon of ibe specjfic volume dunng shock coupression, with samultancous cnergy litcratuon duc to reachon, is given by the equalkon for the Hugentot adrabatuc describung a comblustor wave

$$
P_{1} V_{1}-P_{n} V_{n}(k-1)=\left(V_{n}-V_{1}\right)\left(P_{4}+P_{1}\right) / 2+Q
$$

T'hus equation can be rewnilen as

$$
\begin{aligned}
& \pi-(z(k+1)-(k-1) y)((k+1)-\varepsilon(k-1))+
\end{aligned}
$$

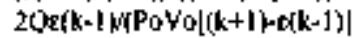

and when 31 is taken inlo account thal the multipliet of $Q$ for $\varepsilon$ of ig grealer than 0 , it is evidem tha $\pi$ for the dynamic compression in a deloration wave is hugher than the curregponding $\pi$ in $a$ shock wave vilhout reaction Figure A-1 contans two hugonnol adızhat|c plots of pressure setsus volume for a stmple shock wave and for a delonation tadve 
Figure A-I Shock W/aves I (in the Atsence of Reaction) AZ and

2 For a Combustion Wave GFEDB

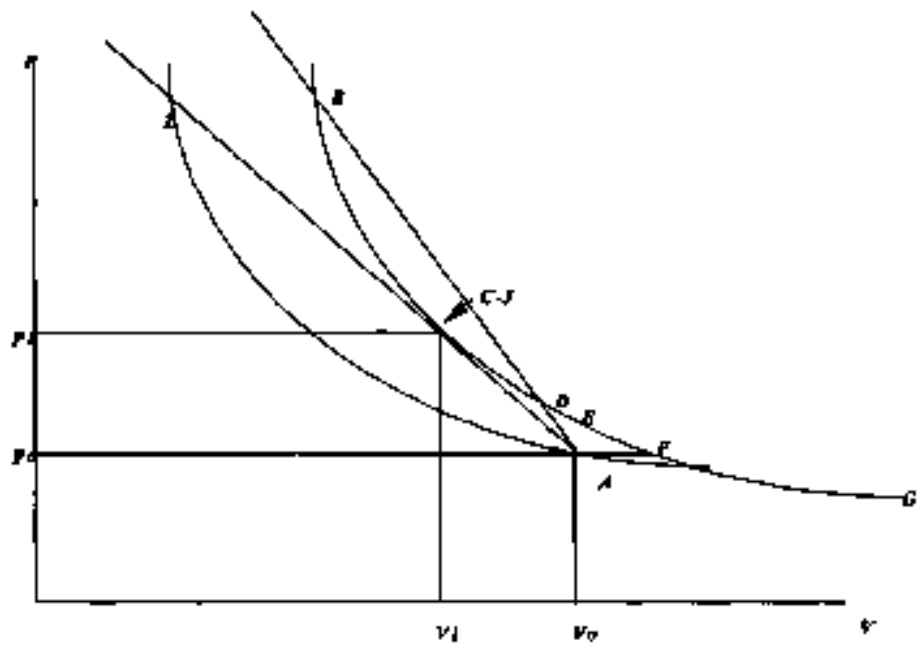

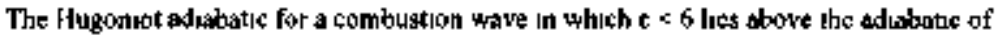
a simple shock wave, which paases through prom $\mathrm{A}$ descritung the inthal state ( $\mathrm{PO} . \mathrm{YB}$ ), is stown chearly in Figure A-I The propalgalion velocily D of the detonsion wave and the gas flow

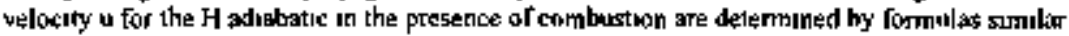
to \{A4). (AS), (A) 2). and (AL 3) lur a simple shurtk wave, but an which $C$ ig repiaced by $D$, the velocity of a detonation urave

Each point on the If adpabatic corrospends io specific volues of D and y Nevertheless, experenents show that tor a given crimpogetion and isilual sate of combustible mixture there is

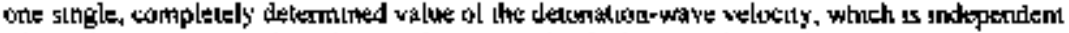
of ali other expenmenal condtiens Consequently, the bassc problepr of detoastom-wave thenty

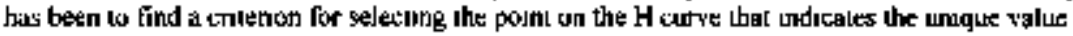
of the velocily of a stationary detonation wave Following fouguel, let us how examine three portions of the $\mathbf{H}$ adrabate lor combuston 
1 The portion below porm $\mathbf{F}$ correspands to combustion accompumad by a lowening

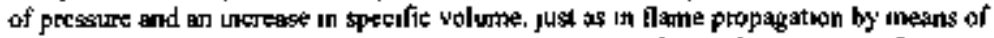
heat conduction and dittusion the propapation velpcily of a cotrbustuon trave for any poilt on the Haduabatk, fuse as for the adjabate of a sumple shock wave, may be delemined from equation (AA) as the producl at the inilial npecufic wollume times

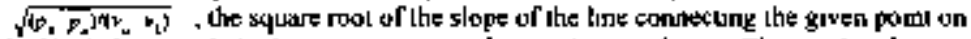

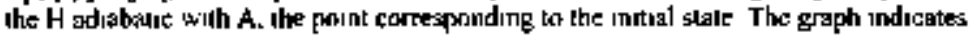

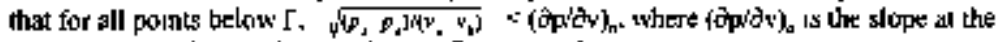
poim corresponding to the istutiol state Consequenily,

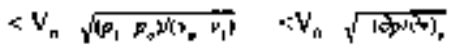

where the right side represents the velocity of sutond in the gas leead of the combustion wwive Evidently, all of the curve helow F corresponds to faraes propagalung al gubsonic velocilleg, generally tefened ta as deflogratuon

2 In porion Eif. a pressure maregse is accrmpanted by an increiste in metific volume

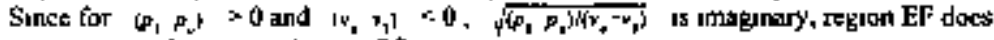
not cotrespond to any real type of (lame propagation

3 The porion above poim $E$ comesponds 10 combugilon accompanied by a pressure rise and a decrease in specific volume. sumbar to the shange in $p$ and $q$ in at shock weve $A$ comparson belween tan of at point $A$, and the slopes of lines drawn from point $A$ to poin's on this branch indicates thal the wast belocjly fur the tulure $t B$ branch is higher than the yelogety of sound C.cinsequently, only the branch of the II earve ]ymg abowe joint E corresponds it a combusion wave wath thinck-wave propernes (dynamic tw shock compression and a supersonec propagiallon velocjty) Chaspman obserying that of all the lines drawi finom the inutial stale porint $F .$. anly one unque point on tranch EBN corresponds to a tangenl, formulated a rute definig the paramelers of a sialkonary

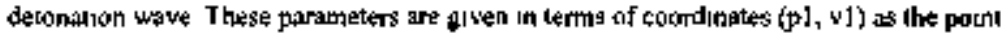


in a lise draw'in trom the intrial sace pouti

The point of tingency is called tlee Chapinal-Joustet (C-J) point, after the founders of the classical theory of the detonaton waye This rule merely is a statemem of the expenmentally

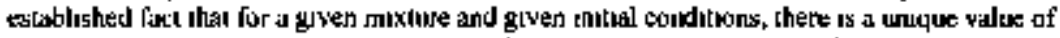
the detonaluon-wave velocity, and is cgsenually an cmpirscal nule To paglify the nule, Jouguet Degin with the faci that in spite of all the vartors possible combusion waves thith supersonic propagal lon velocilies corresponding to di Ifcretst points on the conswdered brathos of the II curve. a detsnetion wave is diglinguished by a slationary nuture

If a detonation wave is to remain stable, the shock wave caututhe the detortiluse ignition in surcessave gas luyers musi not be weukened by the rareficton waves formed duning the

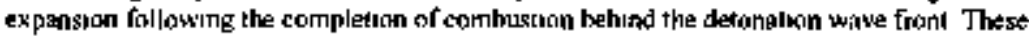


waves, jus as any disturbance. are propagated through the stream behind the detanation wave frone at the velocity of sound

$$
\text { s. }-4 \sqrt{1}
$$

corregpondugg Io the slate of the burthed gas, relaute $w$ the fresh gas ihs propagation lakes place ac the local velocity ot sound $(\mathrm{c},+$ t) Consequenty, a detonouor wave wall not be affected by rareiaction waves odly when

$$
v>c_{1}+\text { y }
$$

S. Ince. as shown directly by oquations (A3) and (A4).

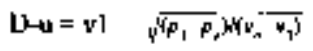

is the veloetty of the siream of compressed gas particles relative to the deinnation-wave fingt, the wonhtion for stibulity of the detonation wave, it that the velocity of the stresm of cumpressed gas behund the detonation wave must not be legs than the velocsly of gound in the given gas, since thes is the propisyation velocity of rarefaction wayes in the gas This condinon for stability of a delonalion wave, formulated by lauguet. provides a partual venfication of the Chapman rule As seen tirnm fingure A-1, $\left.\quad p_{1}-p_{0}\right)\left(v_{*}, p_{1}, \quad\right.$ is the slope of the secionts deawh from A, while the

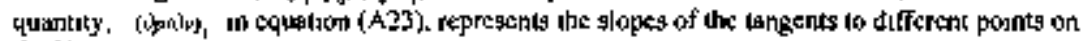
the $\mathrm{H}$ curve

Above the C-J poinl, the angles made by the secapls are snaller than those made by the

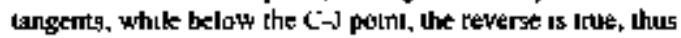

ubove the $\mathrm{C}$-J pont (CI-B brarch), $\mathrm{D}<c_{1}+\mathrm{u}$

helow the $C-1$ momi $\left(C_{j}-E\right.$ hrinch), $D>C_{1}+u$

at the $C-J$ point. $D=c_{1}+u$

The sabplity conditon (A24) is nol fulfillod on the branch of the $\mathrm{H}$ adjalokic aboye the $\mathrm{C}$. J pount, it is fulfilled otly at the CJ pornt and beiow it (on brauch E-CI) It follows from (A25)

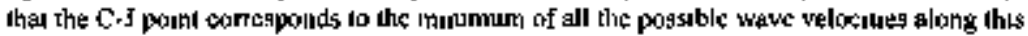
hranch. wheresis the minimum strock-wave veloctiy conresponds to the migimum tmount of kisetic-entergy dis5ipation due to viscosity forces (thal 15, the mimmetm cnaropy morease in the

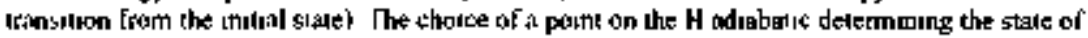
the gas in the detonalion wave. juis as in the clessucial iheory of detonation waves in general, was

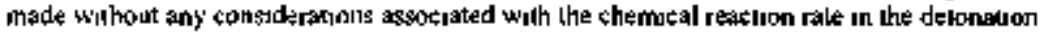
wove It miny be assumed, although the was non formulated explicitly. thal the classical theory 


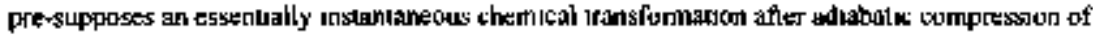
Jhe $\mathrm{m} \mid \mathrm{x}$ (ture in the shoci wave

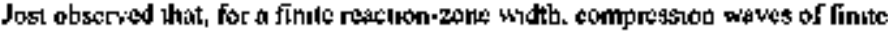
amplilude (that is, correspminding to a figrte increment in mass flow velocity) were generated in the combusion zone al a vertan dıstance from the strock-wave froul (Sukalek 1960), their velocily us inly slightly grealer than the local veloctry of sound, these waves cannot reach the shock - wave frunt, as Jong as its velox'lly is appreclab]y greaser than the local velocily of sound (this is, helow the C-J poust), the conpression waves conlinuously avertake the shock-wave front ronly at the C- 5 poinl As a result. the chrorze of the point of tanyency (C-J) between the $\mathrm{H}$

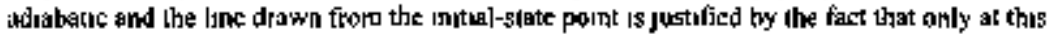
pmint are the condutions completely fulfilled for slability of ptopatgition of a detanalıon wave

This is ifue for the following reasons I) above the C.-] poinl, the shock wave is continuously allenuaned by the actwon of the rarefaction waves formel ifter combustion, 2) betow the C-J point, the finite-amplitade compression waves formed during combuguon cannol rach the thock-wiave and compensate the losses in kinelic energy dive to dissipation, 3 y only al the C-J poim is it inpossible for the strock-wave io become attenusied, and ondy here are the losses in the wase definitely compensaled

The Chapman-Joungel rule keads directly to a method for calculading the velseity and other parameters of a deconationt wave

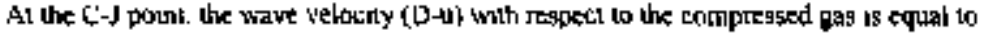

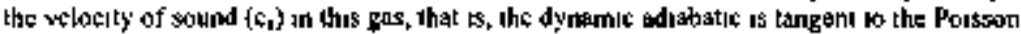
adrabatic for the given inttol stale $\left(p_{1}, v_{1}\right)$

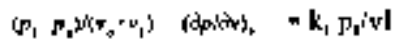

from whtch,

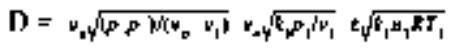

When condruon (A26) w combined wath the equaten for the $\mathrm{H}$ adsabatic for combuston, It is possible to exaluatc $e$ and $n_{1} T_{1}$ in equanion (A27)

If equation (A26) is whinen as

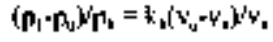

DT

$$
\left.I-p_{N} / p_{1}=\right]-n_{11} R_{0} T_{0} / n_{1} R_{1} T_{1} E=k_{1}(E-1)
$$


thęn we shain

$$
\left.k_{1} \varepsilon^{\prime}-2\left(k_{1}+\right]\right]+H_{h_{1}} R T_{n^{\prime}} n_{1} R T_{1}=[r
$$

whers $\mathrm{n}_{1}$ and $\mathrm{n}_{1}$ ate the number of molcs in a atam of mixture beforc and after cortbusalon, and $k_{1}=C_{j} C_{\text {. }}$ lor the slate af the gat ut the C-J print 'The previous equalion, logether wath the equatoon for the II adratsinge

$$
\begin{aligned}
& C_{v_{1}}\left(T_{1}-T_{v}\right)=Q+V_{2}\left(P_{1}+P_{1}\right)\left(v_{0}-v_{1}\right)= \\
& =Q+1 / S\left(n_{0} R T_{1} / D_{1} R T_{1}+1\right)\left(n_{1} R T_{1}+n_{0} R T_{d} / \varepsilon\right)
\end{aligned}
$$

represent a system of two equations that mates it possible to calleulate $k_{1}, n_{1}$. $T_{1}$, and $\mathbf{E}$ and thus, to define the velocity and outher paranictess of the delonat|on wave Equation (A.26) can be rearranged to obtarsts

$$
\pi=p_{1} i_{n}=1 /\left(1+k_{1}(\varepsilon-1)\right)
$$

Since the denvalions of equation (5) in the main kext and (A3I) have taken different

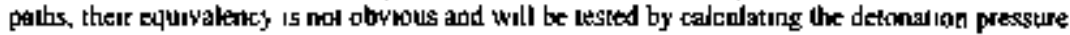
ratio $n$ for a single case and comparing the resulls Let us consuler the sime case as preverusly considered in Tahtle 1 and equation 5

We have already solved for $\gamma_{1}$ and $C_{v 1}$ and can usert them ino equations (A28) and (N29) This leaves 2 equatoons whth 2 unknowisg, 2 and $T_{1}$, and sumulcancous solutrons can be obtarined

Thus Sokalck's $T_{1}$ is 24125 "K and $c$ is $17 \$ 128$

From Sokalek's equastion (A30)

$$
\begin{aligned}
& \pi=\Gamma_{0} i b_{n}=1 /\left(1+k_{1}(E-1)\right) \\
& =1 /\left(1-k_{1}=k_{1}{ }^{*} \varepsilon\right) \\
& -12071
\end{aligned}
$$

This value tô $\pi$ can be compared to the value, 12 066 calculaled abowe from equation (7)

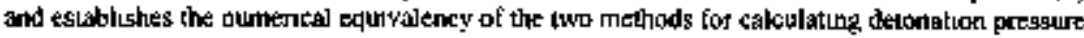
Jatios 


\section{APPENDLX E}

\section{Derivation of Equation A7 $\{E=P V /(k-1)\}$ in Appradir A}

Beginting with ine themondymarne equalion

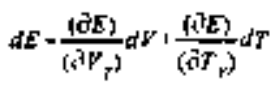

and real Izong that for an uteal cas

$$
\begin{aligned}
& \frac{(\partial E)}{\left(d V_{\tau}\right)} \quad L \text { equal to } 0 \\
& d E \frac{(d E)}{\left(\partial T_{v}\right)} d T
\end{aligned}
$$

now lettung

$$
\begin{aligned}
& \frac{(d E)}{\left(\partial T_{\nu}\right)}-c_{V} \\
& d E=C_{v} d T
\end{aligned}
$$

To untergale the above equatwn

$$
\text { F. E }=T_{+}^{T} C \cos T
$$

If we assume $C$, it he constant

$$
\text { E. } \left.E_{0}-\text { C. (T.T }\right)
$$

Assignang $T_{n}=0 \mathrm{~K}$

and

$$
E_{n}=0
$$




$$
E=C_{*}^{*} T
$$

If $n$ is the number of moles of gas in the system

$$
\begin{aligned}
& n^{*} R^{*} E=C^{*} n^{*} R^{*} T \\
& -C_{4}^{*} P V
\end{aligned}
$$

50

$$
\begin{aligned}
& n * E=C \cdot P V / R \\
& -P V /\left(R / C_{S}\right)=P V /(1+R / C,+1)
\end{aligned}
$$

Thereforc,

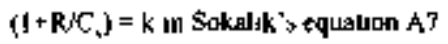

and

$$
n^{*} E-P V /(k-1)
$$

where $n^{*} F$ is the total internal energy of ihe sỵtetn and is equal to Sokalık's $F$, in oquutuon $A$ ?

Since the above denvaluon depersds upun $\mathbf{C}_{\mathbf{v}}$ remaumng conslanl aser the integral

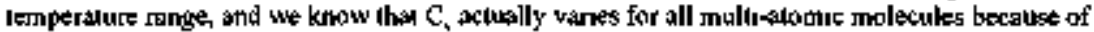



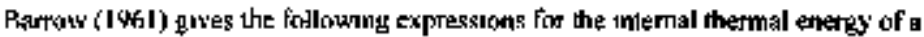
daalome gias

$$
\begin{aligned}
& \text { E.-Eo- 3/2 RT (Trinstatuonil) } \\
& +\mathrm{RT} \text { (Relational) } \\
& +\mathrm{N} \text { e:(Expixt-1) (Vibutiona) }
\end{aligned}
$$

shere $\mathrm{E}$ is the vitwational energy kevel spacing (usual]y about IF. 13 erga/molecule), and

$$
x=\epsilon, n: T
$$

$$
\begin{array}{ll}
d E / d T)=C_{x}-3 / 2 R & \text { (Trans) } \\
+R & \text { (Rot) } \\
+R x^{2} e^{2}\left(c^{x}-1\right)^{2} & \text { (vib) }
\end{array}
$$

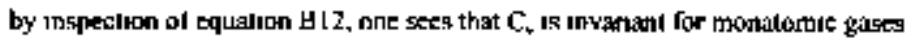


Now xamparing the true indegral

$$
\begin{aligned}
& \left(\mathrm{E} \mathrm{E}_{\mathrm{a}}\right)_{1}=\sigma_{\tau_{0}}^{T t} \mathrm{Cud} \\
& \text { - 7/2 RT (Translabonal) } \\
& +\mathrm{RT} \text { (Rutanınal) }
\end{aligned}
$$

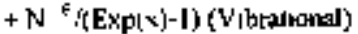

Agansi the equation resulturg from a congrani $C$.

$$
\text { E-E } E_{2} \rightarrow[1 / 2 R \text { (Trâns) }
$$

$+\mathbf{R}$ (Rot)

$$
\left.+R x^{*} e^{*} /\left(z^{*}-1\right)^{*}\left(V_{1} b\right)\right]^{*} T
$$

\begin{tabular}{|c|c|c|c|}
\hline Tonperalure & $\left(\mathbf{E}-\mathbf{E}_{\psi_{1}}\right.$ & $\left(E-E_{p}\right)_{2}$ & \% Error \\
\hline $\mathbf{K}$ & callimol & calinnol & \\
\hline 298 & 1480 & 1303 & 549 \\
\hline 1000 & 4968 & 5851 & 119 \\
\hline 20000 & 9936 & 12644 & 797 \\
\hline
\end{tabular}

These calculatkins are summanzed below for a lyped dualome pas

Table B-1 Error in Thermal Finergy; (caleulat|onal)

In cencilusion, the error in calculating the iniemal therriat energy in Sokalik's derivation is zeco for monsetomuc gases, falls in the 5 to $12 \%$ cange for dualorme gases and probably is . 25 $\%$ for chanomo gases

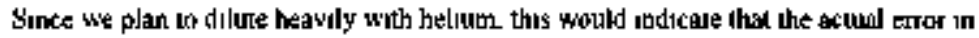
the calculalions mll be very small for our process steps. howcyer tor acesdenl copdotipas wihere air ingeesses, the athoue liacts should be borme in mind 


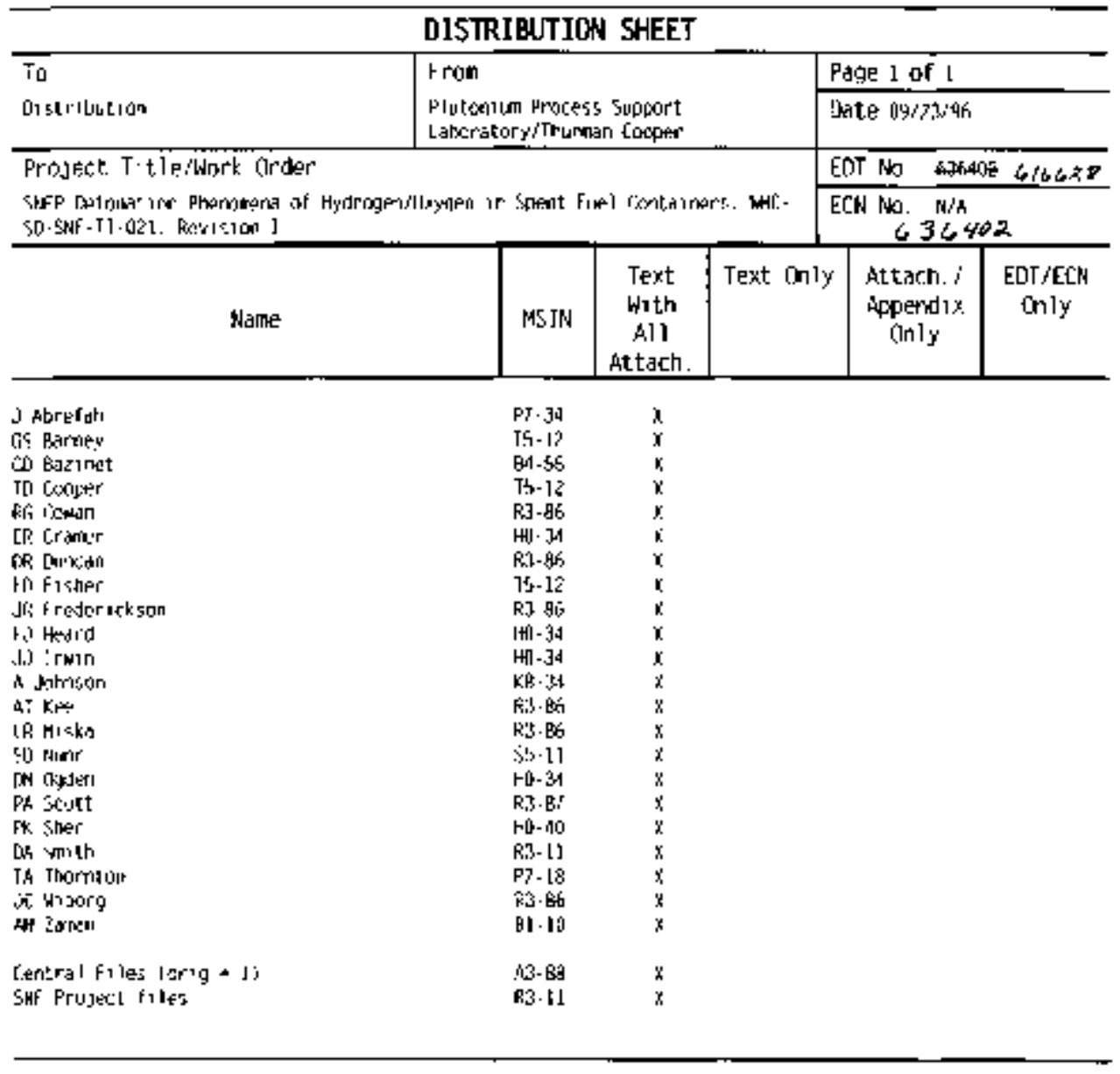

